\title{
BIRD SPECIES RICHNESS, ABUNDANCE AND THEIR FEEDING GUILD ACROSS OIL PALMS DEVELOPMENT THROUGH MIST-NETTING METHOD IN BETONG, SARAWAK
}

\author{
AMIT, B ${ }^{1 *}$; TUEN, A A² and KHO, L K ${ }^{1}$
}

\begin{abstract}
There are a lot of studies comparing birds in oil palm plantation with forests and other crop ecosystems but less on bird across drained peat swamp forest (DPSF) converted to oil palm plantation. This study assessed the bird species richness, abundance and their feeding guild change throughout the oil palm development phases including DPSF, cleared land (CL), one-year-old palm (1YOP), two-year-old palm (2YOP), threeyear-old palm (3YOP), four-year-old palm (4YOP) and five-year-old palm (5YOP). Sixty-seven species of bird were recorded across the development phases through mist-netting method, of which $35.8 \%$ were only recorded in DPSF, 19.4\% of the DPSF bird species continued to be recorded after the forest conversion to oil palm plantation, and $44.8 \%$ of bird species were additional species from DPSF species, appearing following the planting of oil palm. Species richness of bird was significantly higher in DPSF than CL but similar level to those in oil palm plantation. Even though level of species richness in oil palm plantation was similar level to those in DPSF, Non-metric Multidimensional Scaling revealed that bird compositions were different according to the three grouping habitats; DPSF, CL and oil palm plantation. Species richness of insectivorous guild was ranked higher along the oil palm development phases. Species abundance of insectivorous was ranked higher at the early stage of development then omnivorous guild recorded abundant once the Yellowvented Bulbul started to dominate oil palm of more than 2YOP. Good understanding on bird's distribution change across the conversion of forest to oil palm development gives a better idea on how to minimise land disturbance during plantation operations.
\end{abstract}

Keywords: oil palm, omnivorous, peat swamp forest, species richness.

Received: 1 October 2020; Accepted: 2 February 2021; Published online: 27 April 2021.

\section{INTRODUCTION}

Being one of the mega biodiversity countries, Malaysia is committed to the pledge at the Earth Summit in 1992, to keep at least 50\% of its land

\footnotetext{
Malaysian Palm Oil Board,

6 Persiaran Institusi, Bandar Baru Bangi,

43000 Kajang, Selangor, Malaysia.

2 Universiti Malaysia Sarawak,

Institute of Biodiversity and Environmental Conservation, 94300 Kota Samarahan, Sarawak, Malaysia.

* Corresponding author e-mail: bettycopa@mpob.gov.my
}

as forest cover and the protection of Malaysia's forestland cannot be compromised (Parveez et al., 2019). Oil palm is an important commodity crop to Malaysia and with approximately 5.9 million hectares of cultivation, the industry is committed in addressing issues related to sustainability and its safety put forward by global concern (Parveez et al., 2020).

Across a range of agricultural systems, there is a general pattern of biodiversity change when natural habitats are converted to agricultural areas, and further change of biodiversity as such systems are intensified (Donald, 2004). The conversion of 
forest into oil palm plantation systems has resulted in reduced biodiversity as compared to the native forest (Gibson et al., 2011; Hawa et al., 2016; Pimm et al., 2014; Savilaakso et al., 2014). To minimise the disruption on the pattern of biodiversity, various studies have been conducted to enhance biodiversity level within an oil palm plantation, including retaining forest remnants (Laurance et al., 2018), promoting greater landscape heterogeneity (Azhar et al., 2011), and increasing riparian reserves width to $40 \mathrm{~m}$ for each river (Mitchell et al., 2018).

Birds are good indicators to examine the degree of habitat disturbance (Barlow and Peres 2004), fragmentation effects of the conservation value of tropical rainforest (Campbell and Reece, 2002; Mohd-Azlan et al., 2019), landscape-scale processes (Pearman, 2002), florististic composition and availability of food resources (Barlow and Peres, 2004). This is mainly because they respond quickly to changes in vegetation structures and compositions. According to Stouffer and Bierregaad (1995), birds are specialists in their foraging techniques and habitat preference. For example, they use specific habitats and microhabitats and require large territories for their survival. Monitoring birds can show early warning of environmental changes (Gregory et al., 2003) and as well as important agents for seed dispersal and pollination (PadoaSchioppa et al., 2006), pest control in agricultural environment (Koh, 2008a), and habitat quality and changes (Mohd-Azlan et al., 2019). The species composition (richness and abundance) of birds at each habitat is likely to be influenced by various processes associated with habitat structure, food availability, microclimate changes and spatial variations (Sodhi and Smith, 2007; Yap et al., 2007).

There have been several studies of bird in the literature reporting peat swamp forest is more diverse than that in oil palm plantation, and these results are likely attributed to peat swamp forest having complex habitat structure, better habitat, greater plant diversity and food resources (Azhar et al., 2011; Posa, 2011; Yule, 2010). Habitat structure change along the oil palm development phases is expected to be primary determinant of bird diversity over the development, yet few researchers have documented it. In the recent decades, there has been increasing interest in suggesting best management practices to promote bird diversity in oil palm landscape. There are several best practices in oil palm production as suggested by Azhar et al. (2013) which imply the occurrence of bird diversity according to feeding guild. For example, maintaining ground layer vegetation cover, pruning of oil palm canopy to permit light penetration to ground layer, re-vegetation of parts of oil palm landscapes with native trees and retention of natural and / or secondary forest patches within the boundaries of the plantation.
Most of the literatures on the bird species richness were focused on the comparison between oil palm plantation with forests and other agriculture activities (Jambari et al., 2012; Koh, 2008b; 2008c) which were located at different locations. There were research studies focusing on bird species richness that compared logged peat swamp forest with oil palm plantation with different ages and management (Azhar et al., 2011; Azman et al., 2011; Hawa et al., 2016). In addition to these primary data, investigation on bird starting from drained peat swamp forest to oil palm plantation are still needed for a better understanding of their species richness, abundance and feed guild change overtime. Drainage system is common in oil palm plantation on peatland for water management (Hasnol et al., 2010) and flood control (Azhar et al., 2013). Establishment of road and drainage system were carried out in the early operating procedure before clearing logged peat swamp forest for oil palm development (Harun et al., 2011). Hence, the aim of this article is to study the bird changes in species richness and abundance, and their feeding guild following the conversion of DPSF to planting with oil palm and until the palm reached five years old.

\section{MATERIALS AND METHODS}

\section{Study Site}

The study was conducted in an oil palm plantation located on peatlands and covered an area of 3100 ha in Betong Division, Sarawak, Malaysia (Figure 1). Bird surveys were conducted between July 2013 and November 2019. During this period, the study site was developed as oil palm plantation over several phases from the DPSF to cleared land (CL) and planted with oil palm from one-year-old (1YOP) to five-year-old palms (5YOP). DPSF is defined as logged peat swamp forest that has been drained for establishment of main road and drainage system according to plantation blocking before clearing phase for construction of field drains, planting rows and harvesting paths. CL phase is defined as the area that has been cleared for planting oil palm. Four sampling sessions (4320 net/ $\mathrm{hr}$ ) were carried out for each of the oil palm development phases except for CL phase (3240 net/hr). For each sampling session, two replicate sites that have undergone similar development were selected (Site A and Site B), and sampling was conducted repeatedly from both sites to monitor changes of bird population over time. We only completed three sampling sessions in CL phase due to the site being planted immediately after clearing. The surrounding area consisted of peat swamp forest and oil palm plantation belonging to other company. The distance between both sites was $1 \mathrm{~km}$ apart and the nearest forest 


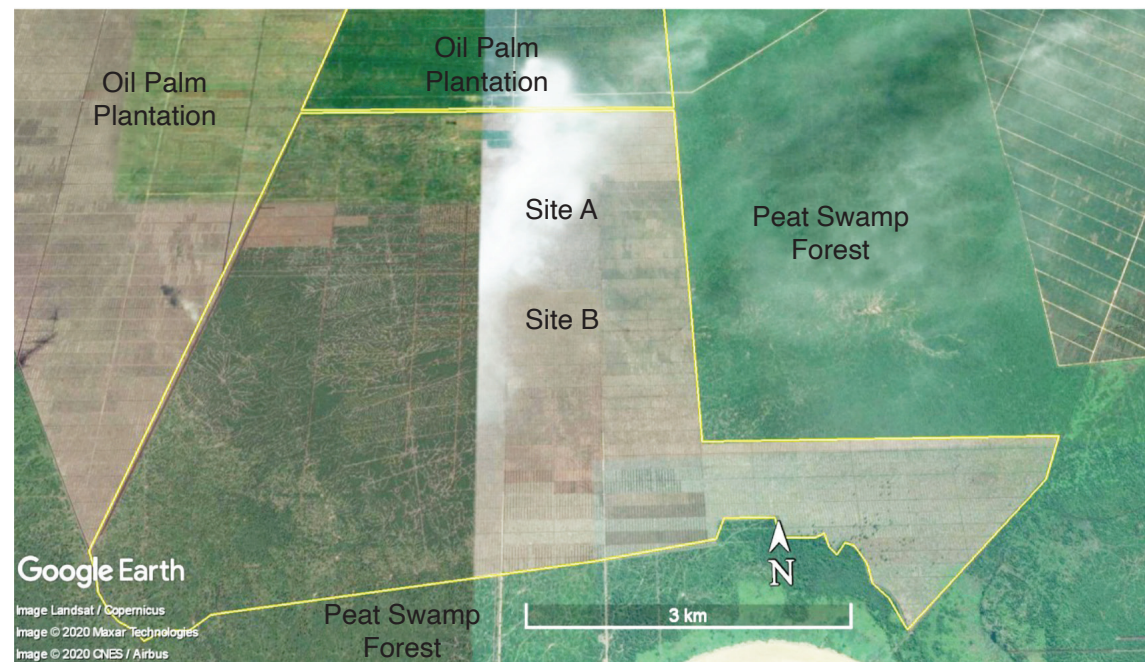

Figure 1. Study site location in Betong, Sarawak, Malaysia.

close to Site A and Site B was $1 \mathrm{~km}$ apart. After the CL was planted with oil palms, the natural vegetation such as Nephrolepis biserrata, Melastoma sp., and Stenochlaena palustris grow naturally on the ground until the palm reached two years and nine months. Spraying activities started before the palms reached three-years-old and this operation only focused at palms circle and harvesting path. Harvesting activities started once the palms reached three years.

\section{Bird Sampling}

In this study, a total of 15 mist-nets [12 m (long) x $2.6 \mathrm{~m}$ (height) $\times 30 \mathrm{~mm}$ (mesh-size)] were set up at each site (two sampling sites) to capture birds (Hawa et al., 2016). This method restricted our samples to bird flying within the height range between 0.5-3.0 $\mathrm{m}$ above the ground. In the newly planted oil palm sites, the nets were set up at the harvesting path in the plantation. The nets were laid out for three days from 0600-1800 hr with regular inspections every $2 \mathrm{hr}$ interval. Captured birds were gently disentangled from the net and were placed separately in the cloth bags. The captured birds were identified to the species level at the camp site and ringed before being released immediately at the site of capture to reduce stress. Ring was used to avoid double counting for similar individual at the same sampling period (Sutherland et al., 2004). Species identification was based on Myers (2009) and Phillipps and Phillipps (2014). The feeding guild of the bird species were grouped into five classes according to the bird species and food resources at the study sites (Phillipps and Phillipps, 2014). Classes of feeding guild involved in this study were namely; insectivorous (feeds on insect and small invertebrate), carnivorous (feeds on vertebrates), omnivorous (feeds on insect, vertebrates and plant parts), granivorous (feeds on grains or seeds) and frugivorous (feeds on fruits).

\section{Data Analyses}

R statistical software version 4.00 (R Core Team, 2020) was used to estimate analyses as mentioned below using package 'vegan' by Oksanen et al. (2007). Shannon index, $\mathrm{H}^{\prime}$ was used in this study to calculate the species diversity of birds at different oil palm development phases. Species diversity can be measured if we have the number of species and the number of individuals in a given area or in a given sample (Spellerberg and Fedor, 2003). Pielou's evenness $(J)$ was used to measure how homogeneous or even a community or ecosystem is in terms of the abundances of its species. A community in which all species are equally common is considered even and has a high degree of evenness. $J$ compares the actual diversity value (such as the Shannon Index, $H^{\prime}$ ) to the maximum possible diversity value (when all species are equally common, Hmax $=\ln S$ where $S$ is the total number of species). $J$ is constrained between 0 and 1.0, and the more variation in abundances between different taxa within the community, the lower the $J$. One-way analysis of variance (ANOVA) was used to compare species richness and abundance among development phases. Once the p-value was less than 0.05, Tukey honestly significant difference (HSD) tests were used to test for significant differences in terms of species richness and abundance between phases. To determine the similarities of the bird community in seven development phases we 
performed an ordination of sites, based on the number of individuals of bird of each species at each site, using Non-metric Multidimensional Scaling (NMDS). To determine whether the bird composition was significantly different among sites we implemented Analysis of Similarity (ANOSIM).

\section{RESULTS}

\section{Species Richness and Abundance}

Across the seven development phases, we captured 715 individual birds representing 67 species, of 32 families (Table 1), including 10 migratory species and two Bornean endemics (Bornean Brown Barbet, Calorhamphus fuliginosus and Dusky Munia, Lonchura fuscans). We recorded 37, 3, 14, 21, 19, 20 and 19 bird species in DPSF, CL, 1YOP, 2YOP, 3YOP, 4YOP and 5YOP, respectively. The calculation in this data suggests that species richness of bird was reduced $43.34 \%-62.16 \%$ from the total number of species recorded in DPSF. Only one species was recorded in all development phases, Oriental Magpie Robin (Copsychus saularis). Our species accumulation curves approached an asymptote for all sites and confirming that we had sampled the avifauna well enough to assess differences in richness between sites except for 4 YOP which was still rising and has not shown any sign of levelling off to reach asymptote suggesting more species to be recorded through longer and more intensive sampling (Figure 2). Species of conservation concern comprised 15\% of all species recorded across the development phase. Interestingly, oil palm plantation recorded

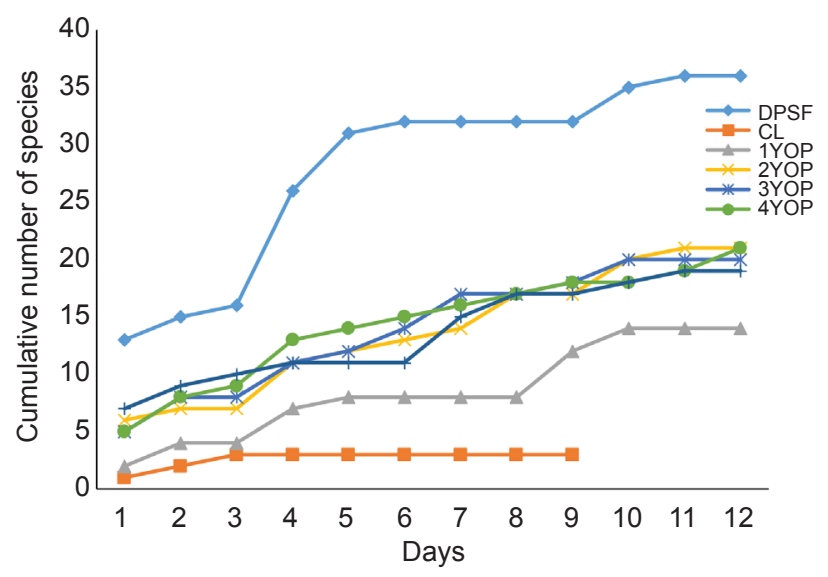

Note: DPSF - drained peat swamp forest; CL - cleared land; 1YOP - one-year-old palm; 2YOP - two-year-old palm; $3 Y O P$ - three-year-old palm; 4YOP - four-year-old palm.

Figure 2. Cumulative number of bird species vs. cumulative days for each development phases. one globally threatened and two near-threatened species, Hook-billed Bulbul (Setornis criniger) and Black-throated Babbler (Stachyris nigricollis), with Grey-chested Jungle Flycatcher (Cyornis umbratilis). Unexpectedly, we captured peat swamp forest specialist species, Hook-billed Bulbul at 3 YOP.

Of the 67 species of birds recorded in this study, $35.82 \%$ were recorded only in the DPSF, $46.27 \%$ were recorded only in the plantations and $17.91 \%$ were recorded both in the plantations and forest. Out of 37 species of birds recorded in DPSF, 3\%$22 \%$ bird species continued to be recorded after forest conversion to oil palm plantation $(<5$ YOP $)$ and 9, 15, 13, 12 and 13 additional species from the species recorded in DPSF species were recorded in 1YOP, 2YOP, 3YOP, 4YOP and 5YOP, respectively (Figure 3). In this study, Yellow-vented Bulbul, (Pycnonotus goiavier), C. saularis and Plaintive Cuckoo (Cacomantis merulinus) were birds recorded relatively abundance in oil palm phases as compared to DPSF (Table 1).

Our results indicated a significant difference in species richness $(\mathrm{p}<0.05)$ between DPSF (mean=13.25 species per sampling) and the CL (mean=1.67 species per sampling) but similar to those in palms in the ages of less than 5YOP (Figure 4). There was no significant difference in bird abundance $(p>0.05)$ caught between different phases. Bird Shannon diversity index was greater in DPSF than CL and young palm. Species abundances were more evenly partitioned at the 1YOP and DPSF than CL and 2YOP until 5YOP. NMDS showed that the bird community (ANOSIM: the number of permutations = 999; Global R: 0.5378; $\mathrm{p}=0.001$ ) showed three clear habitat groupings; DPSF, CL and oil palm plantations (Figure 5).

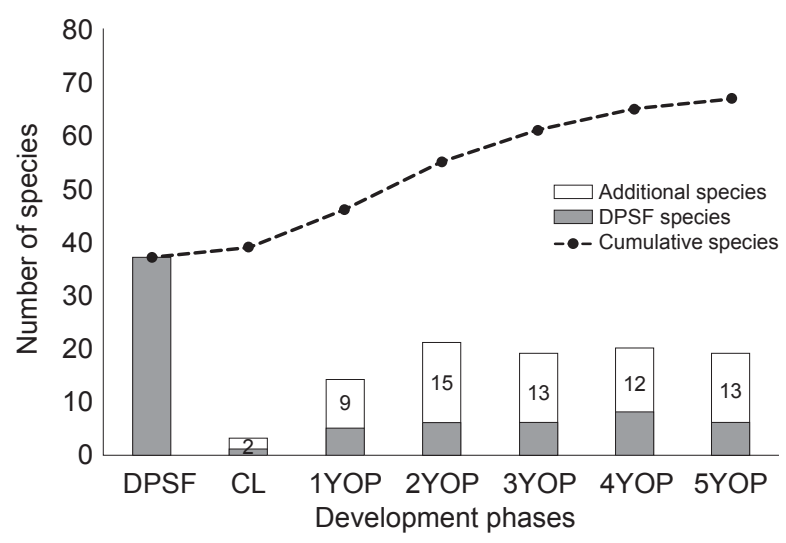

Note: DPSF - drained peat swamp forest; CL - cleared land; 1YOP - one-year-old palm; 2YOP - two-year-old palm; $3 Y O P$ - three-year-old palm; 4YOP - four-year-old palm; $5 Y O P$ - five-year-old palm.

Figure 3. Cumulative species and additional species of drained peat swamp forest (DPSF) bird recorded at different oil palm development phases. 



Note: DPSF - drained peat swamp forest; CL - cleared land; 1YOP - one-year-old palm; 2YOP - two-year-old palm; 3YOP - three-yearold palm; 4YOP - four-year-old palm; 5YOP - five-year-old palm.

Figure 4. Boxplots demonstrating species richness, abundance, Shannon index and Pielou's evenness in relation to habitat changes across the forest conversion to oil palm plantation (one to five-year-old palms).



Note: DPSF - drained peat swamp forest; CL - cleared land; 1YOP - one-year-old palm; 2YOP - two-year-old palm; 3YOP - three-year-old palm; 4YOP - four-year-old palm; $5 Y O P$ - five-year-old palm.

Figure 5. Non-metric multidimensional scaling (NMDS) ordinations of bird community structure across conversion of drained peat swamp forest (DPSF), cleared land (CL) to oil palm plantation. 


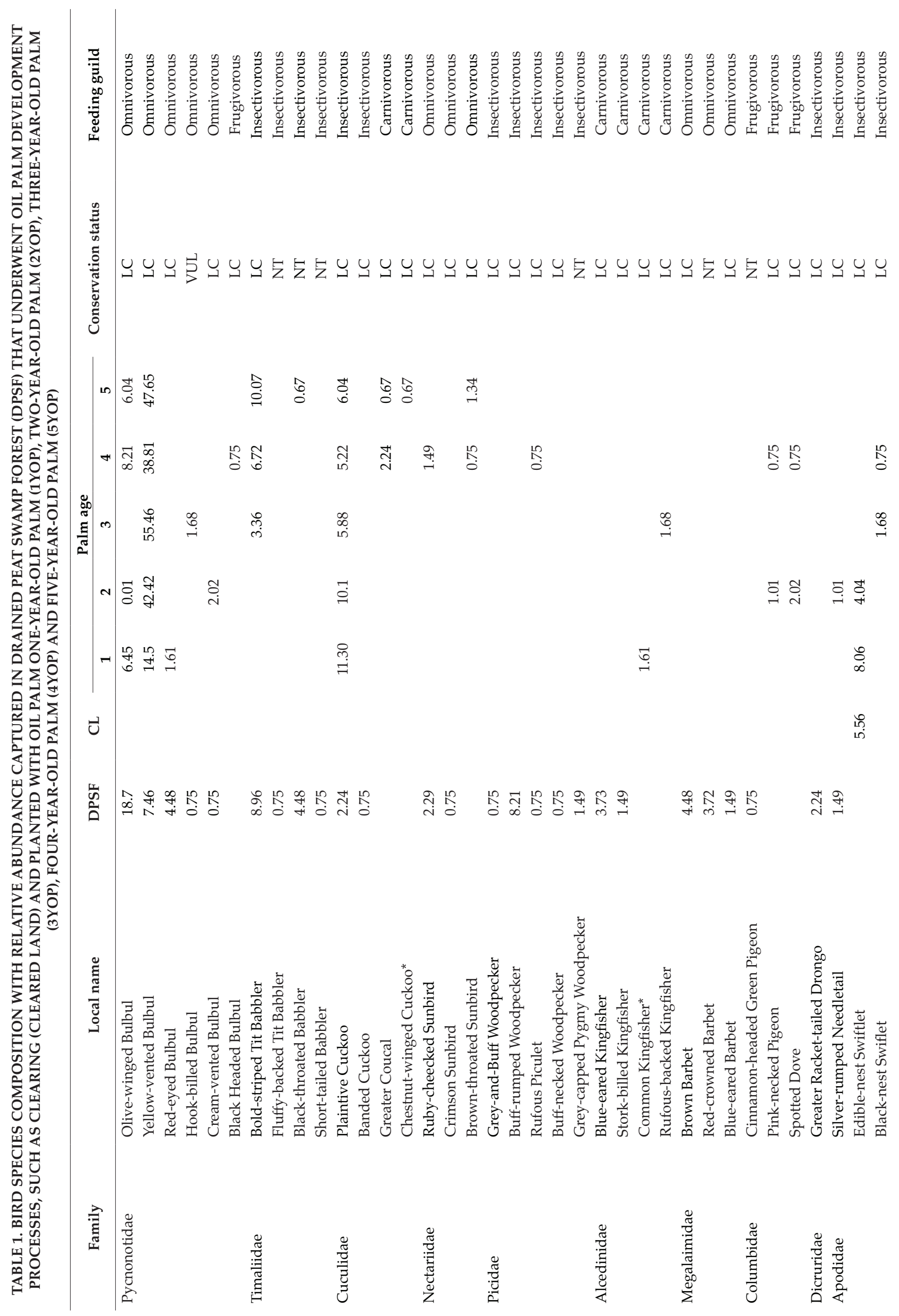




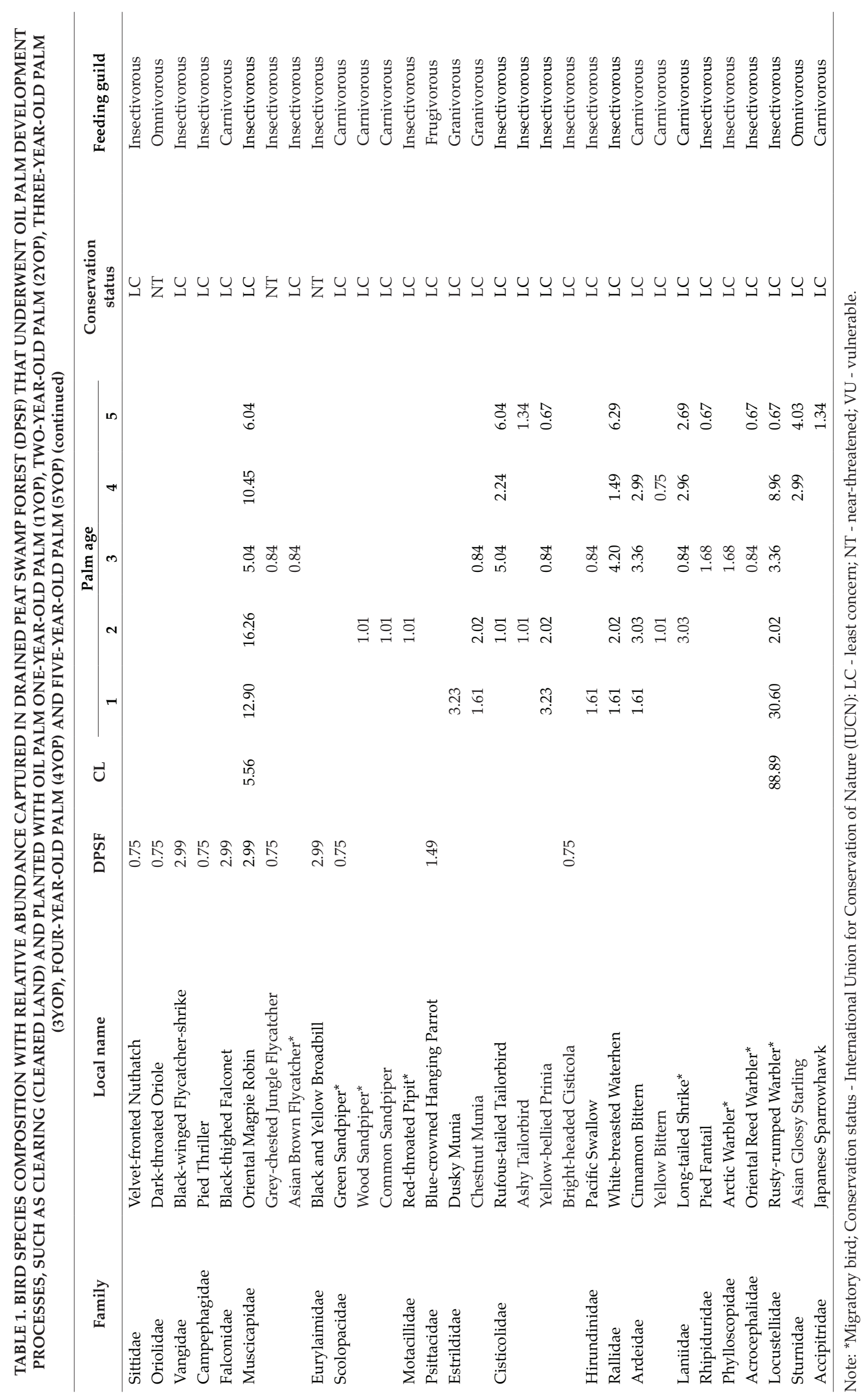




\section{Feeding Guild}

Based on the results, out of 67 species recorded in this study, $49.25 \%, 20.90 \%, 19.40 \%, 7.46 \%$ and $2.99 \%$ were insectivorous, carnivorous, omnivorous, frugivorous and granivorous birds, respectively. Our results show that, the insectivorous guild recorded highest in species richness in all development phases but recorded only second in terms of species abundance starting 2YOP until 5YOP after omnivorous guild. There was no significant difference in insectivorous species richness and abundance between sites $(p>0.05)$. During $C L$ phase, there was no other guild recorded except for insectivorous. It was found that frugivorous guild was only recorded in the DPSF, 3YOP and 4YOP phases while granivorous guild was only recorded at the early stage of oil palm development (1YOP, $2 Y O P$ and $3 Y O P$ ).

Based on the results from Table 2, insectivorous (mean=6.8 species and 15.5 individuals per sampling) in DPSF was the most diverse and abundance guild followed by omnivorous (mean=5.0 species and 13.5 individuals per sampling), carnivorous (mean $=1.0$ species and 2.8 individuals per sampling) and frugivorous (mean $=0.5$ species and 0.75 individuals per sampling). None of the granivorous guild has been recorded in DPSF. Diverse insectivorous guild in DPSF was contributed by a good representation of bird species from woodpeckers (Family Picidea) and bulbuls (Family Pycnonotidae) with five species each. The Olive-winged Bulbul, Pycnonotus plumosus from omnivorous guild was the most dominant species recorded in DPSF with 25 individuals, followed by Bold-striped Tit Babbler, Macronus bornensis with 12 individuals, and Buff-necked Woodpecker, Meiglyptes tukki with 11 individuals. Macronus bornensis and M. tukki were species categorised as insectivorous guild. Carnivorous guild in DPSF was well represented from family Alcedinidae (kingfisher). Frugivorous birds recorded in the DPSF were pigeons, barbets and parrots which mostly fed on fruits.
Meanwhile, in our survey of CL, 100\% (three species) were insectivorous birds. During land clearance, one species each from Locustellidae, Apodidae, and Muscicapidae family were recorded. A total of $88.89 \%$ of the individual birds recorded in the CL were Rusty-rumped Warbler, Locustella certhiola. In this study, this species was recorded until the palm reached $5 Y O P$.

After planting with oil palm, our results indicated that young palm $(<5$ years $)$ could potentially comprise of $40 \%-70 \%$ more diverse insectivorous guild than other feeding guilds (omnivorous: $10 \%-25 \%$, carnivorous: $14 \%-29 \%$, frugivorous: $0 \%-15 \%$ and granivorous: $0 \%-14 \%$ ) with most of the insectivorous guild coming from Cisticolidae family (tailorbirds, prinias). Insectivorous bird, L. certhiola was still dominant in the first year of planting oil palm, however, omnivorous bird namely Yellow-vented Bulbul drastically increased in number and became dominant starting from 2YOP until 5YOP with more than $45 \%$ from the total individuals recorded in each palm age. Omnivorous guild recorded in the plantation was contributed by the presence of Pycnonotidae family (bulbuls). The carnivorous guild in oil palm plantation were represented by wetland bird and small bird predators. In turn, these birds were preyed upon by small predators, such as Long-tailed Shrike (Lanius schach) and Greater Coucal (Centropus sinensis) which occurred abundantly in the early stage of oil palm plantation. Frugivorous guild recorded in the plantation block were mostly seed and fruit eaters, such as spotted dove. This species was not recorded in the DPSF but was captured at 2 YOP and 5YOP. Furthermore, this species was spotted feeding on loose fruits on the roads. Granivorous birds were only recorded at the early stage of oil palm development (1YOP, $2 Y O P$ and 3YOP) and these species, L. fuscans and Chestnut Munia (Lonchura atricapilla) were grass seeds eaters on the plantation blocks.

TABLE 2. DISTRIBUTION OF MEAN SPECIES AND INDIVIDUALS IN FEEDING GUILDS IDENTIFIED IN DRAINED PEAT SWAMP FOREST (DPSF), CLEARED LAND (CL), ONE-YEAR-OLD PALM (1YOP), TWO-YEAR-OLD PALM (2YOP), THREEYEAR-OLD PALM (3YOP), FOUR-YEAR-OLD PALM (4YOP) AND FIVE-YEAR-OLD PALM (5YOP) THROUGH MIST-NETTING METHOD IN BETONG, SARAWAK, MALAYSIA

\begin{tabular}{|c|c|c|c|c|c|c|c|c|c|c|c|c|c|c|}
\hline \multirow{2}{*}{ Feeding guild } & \multicolumn{7}{|c|}{ Mean number of species per sampling } & \multicolumn{7}{|c|}{ Mean number of individuals per sampling } \\
\hline & DPSF & CL & 1YOP & 2YOP & 3YOP & 4YOP & 5YOP & DPSF & CL & 1YOP & 2YOP & 3YOP & $4 Y O P$ & 5YOP \\
\hline Overall & 37 & 3 & 14 & 21 & 20 & 20 & 19 & 134 & 18 & 62 & 99 & 119 & 134 & 149 \\
\hline Insectivorous & 6.80 & 1.80 & 4.00 & 4.75 & 6.50 & 4.75 & 5.50 & 15.50 & 6.0 & 10.75 & 10.00 & 10.75 & 12.25 & 13.00 \\
\hline Omnivorous & 5.00 & - & 2.00 & 1.50 & 1.25 & 2.50 & 3.00 & 13.50 & - & 3.50 & 11.30 & 17.00 & 17.00 & 22.00 \\
\hline Carnivorous & 1.00 & - & 0.50 & 2.00 & 1.50 & 1.75 & 1.00 & 2.80 & - & 0.50 & 2.00 & 1.75 & 3.00 & 2.00 \\
\hline Frugivorous & 0.50 & - & - & 0.75 & - & 0.50 & 0.25 & 0.75 & - & - & 0.75 & - & 0.50 & 0.25 \\
\hline Granivorous & - & - & 0.50 & 0.50 & 0.25 & - & - & - & - & 2.25 & 0.50 & 0.25 & - & - \\
\hline
\end{tabular}




\section{DISCUSSION}

The findings highlight that the logged peat swamp forest that has been drained for oil palm plantation supported higher bird species richness than CL. DPSF supported comparable levels of bird species richness to young palms at the age of less than five years old, and eight times higher than CL. Higher species richness in DPSF than CL has been attributed to the availability of complex habitat structure, better food resources and better habitat shelter in the forests (Azhar et al., 2011; Hawa et al., 2016; Posa, 2011). There was no significant difference in species richness among different ages of young palms and this result is similar to the findings by Azhar et al. (2011) and Aratrakorn et al. (2006). This study reveals that converting DPSF to oil palm plantation may potentially reduce $43 \%-62 \%$ of the bird species. This is consistent with the findings by Azhar et al. (2013) whereby converting forests to oil palm plantation possibly remove $48 \%-60 \%$ of bird species. The research study by Aratrakorn et al. (2006) also found that conversion of forest to plantations results in a reduction of species richness of at least $60 \%$. While there were many additional species appearing after converting DPSF to oil palm plantation such as tailors, prinias, bitterns, swiflets, munias, swallows, waterhen, warblers, shrike and sparrowhawk. This result indicates that new species compositions were formed after transition from DPSF to oil palm plantation and this finding was supported though our NMDS ordination plot showing three clear grouping habitat along the development phases. Aynalem and Bakele (2008) suggested that distribution and abundance of bird are determined by the composition of the vegetation and surrounding landscape that forms a major component of their habitat. We had a surprising results, we managed to capture large-sized bird species such as Chestnut-winged Cuckoo and Japanese Sparrowhawk in oil palm plantation and this finding is similar to the study conducted by Hawa et al. (2016).

Of the 10 Globally Threatened and NearThreatened species (IUCN, 2020) recorded in this study, three species were recorded in oil palm plantation and the others were restricted to DPSF. Out of these three species, one species was known as specialist species to peat swamp forest by Sheldon (1987) namely, S. criniger and two individuals from this species were recorded at 3 YOP. The abundance of this species in peat swamp forest is due to ecological release from competitor (Sheldon et al., 2014). The presence of this species, possibly for foraging activities in the oil palm plantation, was due to the adjacent peat swamp forest located $1 \mathrm{~km}$ from the sampling site.

Insectivorous birds from the families Picidae (woodpeckers) and Pycnonotidae (bulbuls) were recorded to be diverse in the DPSF. The finding is consistent with previous studies at peat swamp forest (Azhar et al., 2013; Hashim and Ramli, 2013; Peh et al., 2006; Sheldon et al., 2010). Good representation of woodpeckers in peat swamp forest is due to the existing remnants of dead standing trees found in the peat swamp forest which would attract bark-gleaning and hole-nesting birds for foraging and nesting activities (Styring and Zakaria, 2004). Interestingly, in CL abundance of insectivorous migratory bird, L. certhiola showed that this species was attracted to the newly opened peat swamp land which was consistent with the findings of Phillipps and Phillipps (2014) who stated that the presence of this species is due to their preference for open wetland area for their foraging activity. Our findings suggest that insectivorous guild recorded highest in species richness in oil palm plantation than other guilds and this guild was well-represented by the family Cisticolidae (tailorbirds, prinias). The primary contributor was the presence of ground layer of natural vegetation which attracted a high number of arthropods (Azhar et al., 2013; Hood et al., 2020; Jambari et al., 2012; Turner and Foster, 2009) hence providing food resources for this guild.

Diverse species of bulbuls in DPSF indicated that these coloniser species are common species recorded in disturbed areas such as regenerating forest from previous logging activities (Hashim and Ramli, 2013; Sodhi and Smith, 2007; Zakaria et al., 2002). Abundance of omnivorous bird, P. plumosus in DPSF indicates that this habitat was common in disturbed forest areas. Uneven species abundance in oil palm plantation was contributed by the presence of omnivorous bird $P$. goivaier as a dominant species starting from 2 YOP, 3 YOP, $4 Y O P$ and $5 Y O P$. This result is in line with earlier literature by Hawa et al. (2016) and Amit et al. (2015) who found that P. goivaier has successfully dominated oil palm plantation due to their preference for diet with diverse range of food from plant materials to arthropods. Plantation practice by maintaining ground-layer vegetation growing naturally provide food resources for this omnivorous bird (Azhar et al., 2013; Hood et al., 2020; Turner and Foster 2009).

Carnivorous guild in DPSF was represented by the family Alcedinidae (kingfisher) while in early oil palm plantation revealed that carnivorous guild was well represented by wetland bird such as Amaurornis phoenicurus, Ixobrychus cinnamomeus and Ixobrychus sinensis and small bird predators such as L. schach and C. sinensis. Construction of drainage systems to control the ground water level in oil palm plantation on peat create habitat for aquatic life hence was more attractive for wetland carnivorous birds due to foraging opportunities (Azhar et al., 2013; Jambari et al., 2012). Diverse birds from family Cisticolidae (tailorbirds, prinias) in oil palm plantation provide food resources for small predators that feed on small 
birds. This finding was observed during sampling period where $C$. sinensis was seen feeding on tailorbirds and prinias captured on the nets.

\section{CONCLUSION}

It is important to understand the changes of bird species richness, abundance and their feeding guild throughout the oil palm development processes so that the effects of land conversion especially on peatland can be reduced and managed. Our study demonstrates that DPSF supported higher bird species richness than CL but similar level to those in early stage of oil palm plantation. This study has shown that species abundance is similar among sites. Good representation of insectivorous guild in terms of species richness in all development phases. Oil palm plantation recorded abundance of omnivorous guild starting at 2YOP until 5YOP. Through letting ground layer vegetation grow naturally and maintaining water quality of the drainage system in the early stage of oil palm development by the plantation management attract birds that prefer to this habitat hence provides food resources for their survival.

\section{ACKNOWLEDGEMENT}

The authors thank the Director-General of the MPOB for permission to publish this article. We also thank the management of the oil palm plantation for their assistance throughout the study. We would also like to acknowledge members of MPOB Peat Ecosystem and Biodiversity Unit for their technical assistance.

\section{REFERENCES}

Amit, B; Tuen, A A; Haron, K; Harun, M H and Kamarudin, N (2015). The diet of Yellowvented Bulbul (Pycnonotus goiavier) in oil palm agroecosystems. J. Oil Palm Res., 27(4): 417-424.

Aratrakorn, S; Thunhikorn, S and Donald, P F (2006). Changes in bird communities following conversion of lowland forest to oil palm and rubber plantations in Southern Thailand. Bird Conserv. Int., 16: 71-82.

Aynalem, S and Bekele, A (2008). Species composition, relative abundance and distribution of bird fauna of riverine and wetland habitats of Infranz and Yiganda at Southern tip of Lake Tana, Ethiopia. Trop. Ecol., 49: 199.

Azhar, B; Lindenmayer, D B; Wood, J; Fischer, J; Manning, A; MCelhinny, C and Zakaria, M (2011).
The conservation value of oil palm plantation estates, smallholdings and logged peat swamp forest for birds. For. Ecol. Manag., 262(12): 2306-2315.

Azhar, B; Lindenmayer, D B; Wood, J; Fischer, J; Manning, A; MCelhinny, C and Zakaria, M (2013). The influence of agricultural system, stand structural, complexity and landscape context on foraging birds in oil palm landscapes. Ibis, 155(2): 297-312.

Azman, N M; Abdul, L N S; Mohd, S S A; Md Akil, M A M; Shafie, N J and Khairuddin, N L (2011). Avian diversity and feeding guilds in a secondary forest, an oil palm plantation and paddy field in riparian areas of the Kerian River Basin, Perak, Malaysia. Trop. Life Sci. Res., 22(2): 45-64.

Barlow, J and Peres, C A (2004). Avifaunal responses to single and recurrent wildfires in Amazonian forests. Ecol. Appl., 14: 1358-1373.

Campbell, N A and Reece, J B (2002). Biology. Sixth edition. Benjamin Cummings, San Francisco, USA. 187 pp.

Donald, P F (2004). Biodiversity impacts of some agricultural commodity production systems. Conservation Biology, 18: 17-38.

Gibson, L; Lee, T M; Koh, L P; Brook, B W; Gardner, T A; Barlow, J; Peres, C A; Bradshaw, C J; Laurance, W F; Lovejoy, T E and Sodhi, N S (2011). Primary forests are irreplaceable for sustaining tropical biodiversity. Nature, 478: 378-381.

Gregory, R D; Noble, D; Field, R; Marchant, J; Raven, M and Gibbons, D W (2003). Using birds as indicators of biodiversity. Ornis Hungarica, 12(13): 11-24.

Harun, M H; Kushairi, A; Mohammed, A T; Omar, W; Othman, H; Darus, F and Jantan, N M (2011). Guidelines for the Development of a Standard Operating Procedure for Oil Palm Cultivation on Peat. MPOB, Bangi. 9 pp.

Hashim, E N and Ramli, R (2013). Comparative study of understorey birds diversity inhabiting lowland rainforest virgin jungle reserve and regenerated forest. Sci. World J., 2013(1): 676507.

Hasnol, O; Tarmizi, A M; Haniff, M H; Darus, F M and Mos, H (2010). Best management practices for oil palm planting on peat: Optimum groundwater table. MPOB Information Series No. 472.

Hawa, A; Azhar, B; Top, M M and Zubaid, A (2016). Depauperate Avifauna in tropical peat swamp 
forests following logging and conversion to oil palm agriculture: Evidence from mist-netting data. Wetlands, 36(5): 899-908.

Hood, A S C; Advento, A D; Stone, J; Fayle, T M; Fairnie, A L M; Waters, H S; Foster, W A; Snaddon, J L; Caliman, J-PP; Naim, M and Turner, E C (2020). Removing understory vegetation in oil palm agroforestry reduces ground-foraging ant abundance but not species richness. Basic Appl. Ecol., 48: 26-36.

IUCN (2020). The IUCN Red List of Threatened Species. International Union for Conservation of Nature. http: / / www.iucnredlist.org/ accessed on 26 April 2020.

Jambari, A; Azhar, B; Ibrahim, N L; Jamian, S; Hussin; Puan, C L and Zakaria, M (2012). Avian biodiversity and conservation in Malaysian oil palm production areas. J. Oil Palm Res., 24: 12771286.

Koh, L P (2008a). Birds defend oil palms from herbivorous insects. Eco. Appl., 18: 821-825.

Koh, L P (2008b). Can oil palm plantations be made more hospitable for forest butterflies and birds? J. Appl. Ecol., 45: 1002-1009.

Koh, L P (2008c). Is oil palm agriculture really destroying tropical biodiversity? Conserv. Lett., 1: 60-64.

Laurance, W F; Carmargo, J L C; Fearnside, P M; Lovejoy, T E; Williamson, B G; Mesquita, R C G and Laurance, S G W (2018). An Amazonian rainforest and its fragments as a laboratory of global change. Biological Reviews, 93: 223-247.

Mitchell, S L; Edwards, D P; Bernard, H; Coomes, D; Jucker, T; Davies, Z D and Struebig, M J (2018). Riparian reserves help protect forest bird communities in oil palm dominated landscapes. J. Appl. Ecol., 55(6): 1-12.

Mohd-Azlan, J; Fang, V A M; Kaicheen, S S; Lok, L and Lawes, M J (2019). The diversity of understorey birds in forest fragments and oil palm plantation, Sarawak, Borneo. J. Oil Palm Res., 31(3): 437-447.

Myers, S (2009). A Field Guide to the Birds of Borneo. New Holland Publishers Ltd. 272 pp.

Oksanen, J; Kindt, R; Legendre, P; O’Hara, B; Simpson, G L; Solymos, P; Stevens, M H H and Wagner, H (2007). Vegan: Community Ecology Package. R Package Version 1.17-8.
Padoa-Schioppa, E M; Baietto, R; Massa and Bottoni, L (2006). Bird communities as bioindicators: The focal species concept in agricultural landscapes. Ecol. Indic., 6: 83-93.

Parveez, G K A; Khoon, K L; Hill, T C; Arn, T Y and Kushairi, A (2019). Sustainable oil palm cultivation in Malaysia - Are peatlands a suitable choice? J. Oil Palm Environment and Health, 10: 13-18.

Parveez, G K A; Hishamuddin, E; Loh, S K; Ong-Abdullah, M; Salleh, K M; Bidin, M N I Z; Sundram, S; Hasan, Z A A and Idris, Z (2020). Oil palm economic performance in Malaysia and R\&D progress in 2019. J. Oil Palm Res., 32(2): 159-190.

Pearman, P B (2002). The scale of community structure: Habitat variation and avian guilds in tropical forest understorey. Ecol. Monogr., 72(1): 19-30.

Peh, K S H; Sodhi, N S; de Jong, J; Sekercioglu, C H; Yap, C A M and Lim, S L H (2006). Conservation value of degraded habitats for forest birds in Southern Peninsular Malaysia. Divers. Distrib., 12(5): 572-581.

Phillipps, Q and Phillipps, K (2014). Phillipps' field guide to the birds of Borneo Sabah, Sarawak, Brunei and Kalimantan. Third edition. Princeton University Press, New Jersey.

Pimm, S L; Jenkins C N; Abell, R; Brooks, T M; Gittleman, J L and Joppa, L N (2014). The biodiversity of species and their rates of extinction, distribution and protection. Science, 344(6187): 1246752.

Posa, M R C (2011). Peat swamp forest avifauna of Central Kalimantan, Indonesia: Effects of habitat loss and degration. Biol. Conserv., 144: 2548-2556.

R Core Team (2020). R: A language and environment for statistical computing. $\mathrm{R}$ Foundation for Statistical Computing, Vienna, Austria. https:// www.R-project.org/, assessed on 29 April 2020.

Razak, S; Saadun, N; Azhar, B and Lindenmayer, D B (2020). Smallholdings with high oil palm yield also support high bird species richness and diverse feeding guilds. Environ. Res. Lett., 15(9): 094031.

RSPO (2020). About. Roundtable on Sustainable Palm Oil (RSPO). https: / / rspo.org/ about, accessed on 6 August 2020. 
Savilaakso, S; Garcia, C; Garcia-Ulloa, J; Ghazoul, J; Groom, M; Guariguata, M R; Laumonier, Y; Nasi, R; Petrokofsky, G; Snaddon, J and Zrust, M (2014). Systematic review of effects on biodiversity from oil palm production. Environ. Evid., 3(1): 4.

Sheldon, F H; Davison, G; Wong, A and Moyle, R G (2014). Birds in Peatswamp at Klias Forest Reserve and Environs, Sabah, Malaysian Borneo. Occasional Papers of the Museum of Natural Science. Louisiana State University, Baton Rouge, Louisiana. No. 83.

Sheldon, F H (1987). Habitat preferences of the Hook-billed Bulbul (Stornis criniger) and the Whitethroated Babbler (Malacopteron albogulare) in Borneo. Forktail, 3: 17-25.

Sheldon, F H; Styring, A and Hosner, P A (2010). Bird species richness in a Borneon exotic tree plantation: A long-term perspective. Biol. Conserv., 143: 399-407.

Sodhi, N S and Smith, K G (2007). Conservation of tropical birds: Mission possible? J. Ornithol., 148(2): 305-309.

Spellerberg, I F and Fedor, P J (2003). A tribute to Claude Shannon (1916-2001) and a plea for more rigorous use of species richness, species diversity and the 'Shannon-Wiener' index. Global Ecol. Biogeogr., 12: 177-179.
Stouffer, P C and Bierregaard, R O (1995). Use of Amazonian forest fragments by understory insectivorous birds. Ecology, 76: 2429-2445.

Styring, A R and Zakaria, H M (2004). Foraging ecology of woodpeckers in lowland Malaysian rain forests. J. Trop. Ecol., 20: 487-494.

Sutherland, W J; Newton, I and Green, R (2004). Bird Ecology and Conservation: A Handbook of Techniques. Oxford University Press, London. 405 pp.

Turner, E C and Foster, W A (2009). The impact of forest conversion to oil palm on arthropod abundance and biomass in Sabah, Malaysia. J. Trop. Ecol., 25: 23-30.

Yap, C A M; Sodhi, N S and Peh, K S H (2007). Phenology of tropical birds in Peninsular Malaysia: Effects of selective logging and food resources. Auk., 124: 945-961.

Yule, C M (2010). Loss of biodiversity and ecosystem functioning in Indo-Malayan peat swamp forests. Biodivers. Conserv., 19: 393-409.

Zakaria, M; Amri, K and Nasir, J (2002). Comparison of understorey bird species composition in a primary and logged hill dipterocarp forest in Peninsular Malaysia. Malay. Nat. J., 56: 153-167. 